\title{
DETERMINING THE FACTORS OF THE EMPLOYEES' INTENTION TO STAY OR LEAVE IN THE SLOVAK'S SMES
}

\author{
Zoltan Rozsa \\ Alexander Dubček University of Trenčín, Faculty of Social and Economic Relations \\ Trencin, Slovak Republic \\ zoltan.rozsa@tnuni.sk
}

\section{Ivo Formánek}

University of Entrepreneurship and Law

Prague, Czech Republic

ivo.formanek@vspp.cz

\author{
Radim Maňák \\ University of Entrepreneurship and Law \\ Prague, Czech Republic \\ radim.manak@vspp.cz
}

\begin{abstract}
A large number of Slovak small and medium enterprises (SMEs) are confronted with often-leaving employees. This situation can have a devastating effect; thus, the ability to predict and early detect the employees' intention to stay or leave to another organisation provides them with a competitive advantage.

Paper aims to determine how employer attractiveness influences the employees' intention to stay or leave to another organisation. The online questionnaire survey was conducted to collect data during the September and October 2019 among 357 Slovak SMEs' employees. The employees' values were described by EmpAt's five dimensions scale. Binary logistic regression was used to predict which employer attractiveness factor leads to an intention to stay in the organisation within the next 6 months. Results show that to the employee's decision to stay working for the organisation contribute Application Value (AV Odds Ratio=2.53), followed by Economic Value (EV Odds Ratio=2.36), Interest Value (IV Odds Ratio=2.23), and Social Value (SV Odds Ratio=1.48). We did not find statistically significant associations between Development Value (DV) and the employees' intention to stay or leave (ISL).

This study makes several contributions to extant human resource management literature. First, it extends the research on employer attractiveness and employee retention. Second, it expands the knowledge about the predictors of employees' intention to stay in organisations. On the managerial level, it recommends that the employees' intent to stay or leave should be regularly measured.
\end{abstract}

KEYWORDS: employer attractiveness, retention, prediction, SMEs

JEL CLASSIFICATION: M51, M54, J81

Received: October $16^{\text {th }}, 2019$

1st Revision: November 21't, 2019

Accepted: December 12 2019

DOI: 10.2478/IJEK-2019-0011

Reference: Rozsa, Z., Formánek, I., Maňák, R. (2019). Determining the factors of the employees’ intention to stay or leave in the Slovak's SMEs. International Journal of Entrepreneurial Knowledge, 7(2), 63-72. doi:10.12345-0011

\section{INTRODUCTION}

Many organisations around the world increasingly focus on the concept of an attractive employer, striving to differentiate themselves from competitors (Mihalache et al., 2010), and sustained competitive advantage to attain economic profit and to survive in an increasingly global and competitive marketplace (Sivertzen et al. 2013). This process is becoming even more critical in small and medium 
enterprises (SMEs) as they play a vital role in job creation (Koisova et al., 2017). Moreover, they are recognized as one of the main contributors to economic, development and employment growth (Cepel et al., 2018; Dahnil et al., 2014; Kljucnikov et al., 2016; Mura, 2019).

However, a large number of companies face with the fact that employees will, for any reason, leave the company. The employees' fluctuation can be a problem if it is too high or too frequent, and also if the company is left by talented employees in which invested significant funds (Pavlovic, 2018). As it is the unemployment rate at its minimum in many developed countries (Mihalache et al., 2010), the severity of the problem is highlighted. The limited supply of highly skilled candidates, combined with high workforce mobility, results in considerable hiring, training, and developing costs (Dabirian et al., 2019). The company's internal potential is most strongly influenced by the potential and commitment of its employees that can be directly influenced by the individual activities of human resources management (Stachová et al., 2019). Ability to predict and early detect the employees' intention to stay or leave to another organisation provide the company with a sustainable competitive advantage.

Previous studies have mainly focused on the influence of employer attractiveness from the view of the recruitment or in other words how to attract better employees (Alnıçı \& Alnıaçık, 2012; Altmann \& Suess, 2015; Ha \& Luan, 2018; Germano et al., 2016). Our approach differs in term to focus on prediction the intention to stay or leave based on employer attractiveness, thereby covering the existing research gap. The paper aims to determine how employer attractiveness influences the employees' intention to stay or leave to another organisation.

This article contains four sections, besides this introduction. In the literature review, the generational issue, the concepts of employer attractiveness and employee retention are reviewed and discussed. Next, the methodological procedures are presented. Then, results are shown and discussed. Afterwards, limitations and suggestions for further studies are presented in conclusion.

\section{THEORETICAL BASES}

This section reviews and discusses the literature considered relevant for the proposed research - the studies on the concepts of employer attractiveness and employees' retention.

\subsection{Employer attractiveness}

Attracting and retaining high-quality human resources has always been highly considered as a decisive factor that impacts directly on an organisation's success (Ha \& Luan, 2018). Organisations thus have always cared about what their employees think and say about them. Collective employee opinions shape not only the loyalty, engagement, and retention of existing workers, but also how firms are seen publicly (Dabirian et al., 2017). The literature offers us diverse definitions of the employer attractiveness (EA) or also how firms are seen publicly. Nevertheless, what they all have in common are the advantages and satisfaction one finds in working for a company (Berthon et al., 2005; Slåtten, Lien, \& Svenkerud, 2019).

EA can be defined as the envisioned benefits that a potential employee could get in working for a specific organisation (Berthon et al., 2005). It can be operationalized as an attitude or affect toward viewing an organisation "as a desirable entity with which to initiate some relationship" (Aiman-Smith et al., 2001) and thus refers to the degree to which potential applicants favourably perceive organisations as good places to work (Jiang et al., 2011; Rynes et al., 1991). We can, therefore, distinguish between two EA views (Uen et al., 2011). In an organisational context, organisational prestige could be considered as a component of EA, implying that the organisation probably has a reputation as an excellent employer. At the individual level, organisational attractiveness refers to applicants who would like to work for the organisation and exert a great deal of effort to work for it (Highhouse et al., 2003). However, we must emphasize that it is not sufficient for the employer to be attractive only during the recruitment phase, but EA must be continuously worked on so that the company becomes a continuously recognized as an attractive employer in the labour market (Breaugh \& Starke, 2000; 
Germano et al., 2016). Therefore, EA influences not only the recruitment processes but also the retention of employees (Helm, 2013) and the intentions to stay in the workplace should be measured separately, along with intentions to choose the workplace (Jiang et al., 2011).

Employer attractiveness has been operationalized and repeatedly measured in different ways. Lievens et al. (2001) investigated which of four objective organisational characteristics (organisation size, level of internationalisation, pay mix, and level of centralisation) determine the attractiveness of organisations for prospective applicants and the degree to which the Big Five personality factors moderate the effects of some of these organisational attributes. Turban (2001) investigate relationships of recruitment activities, organisational attributes, familiarity with the firm, and the social context with a firm's attractiveness as an employer on college campuses. Highhouse et al. (2003) measured attraction to organisations with the three components of organisational attraction (i.e., attractiveness, intentions, and prestige) that have received the most attention in research on organisation choice. Berthon et al. (2005) have extended three-dimensional employer brand structure proposed by Ambler and Barrow (1996) to a five-factor scale for measurement of employer attractiveness (EmpAt) from potential applicants' perspective, comprising Interest value, Social value, Economic value, Development value and Application value. The five items measurement scale was also used by Kausel and Slaughter (2011) to examine whether the use of narrow personality facets, such as trust (under the Big Five trait agreeableness), assertiveness (under extraversion), and imagination (under openness to experience) enhances the prediction of attraction. Bakanauskiene et al. (2017) data analysis revealed that 19 employer attributes are positively linked to organisational attractiveness.

However, we use the scale developed by Berthon et al. (2005) because it has been more frequently used in subsequent studies (Alnıaçık \& Alnıaçık, 2012; Arachchige \& Robertson, 2011; Germano et al., 2016; Sivertzen et al., 2013). The EmpAt's five dimensions described the extent of what the organisation offers its employees the following values. Interest Value (IV): working in an environment that tests employees' ability or determination, with innovative working practices and climate full of creativity. Social Value (SV): pleasant social and interpersonal environment with a good relationship with colleagues and superiors. Application Value (AV): opportunity to apply knowledge, to teach others, to give back to society. Economic Value (EV): excellent promotion opportunities within the organisation, above-average basic salary, an attractive overall compensation package. Development Value (DV): provides recognition, self-worth and confidence, the development of skills and career-enhancing experiences (Bakanauskiene et al., 2017; Berthon et al., 2005; Dabirian et al., 2017; Dabirian et al., 2019; Germano et al., 2016).

\subsection{Employees retention}

Keeping talented individuals have become some of the most crucial objective of human resource management (HRM) practices (Govaerts et al., 2011; Hiltrop, 1999; Pittino et al., 2016). Employee retention is defined as an effort to create and foster surroundings that encourage modern-day personnel to remain employed using policies and practices in place that address their diverse desires (Peter et al., 2019). Respectively, which are used to prevent employees from leaving and to maximize their time of working for the organisation (Cascio, 2019; Kossivi et al., 2016). The reasons why organisations have to deal with employees' retention are as follows. To hire an employee cost a lot of money and time. Retention boosts the organisation's productivity and increases the unity among the staff members (Rakhra, 2018). Often the individuals who leave take proprietary knowledge that is impossible to replace. When employees depart, they often open the door for others to leave the organisation. High employee turnover can have a devastating effect on a company, especially if the lost employees are high performers (Mattox et al., 2005).

Published studies examine a wide variety of factors with an impact on retention. Arasanmi and Krishna (2019) found that perceived organisational support (POS) significantly influence employees' organisational commitment (OC) as a predictor of employee retention. Matogolo et al. (2018) found that reward strategy and people orientedness emerged as significant predictors of retention. Drawing on data from three different managerial respondents in 275 companies based in China, Yu et al. (2019) findings demonstrate the precedential effect of IMO on corporate performance through employees' 
organisational commitment and retention framework. The Mutsuddi and Sinha (2017) study had revealed that employee intention to stay is influenced by social factors as co-worker relations, and trust \& control mutuality. Alzyoud et al. (2019) found a significant relationship between leaders' emotional intelligence and employee retention which can induce a sense of belongingness leading to enhance job satisfaction which further results in harnessing employee retention. Asimah (2018) study revealed that six factors (Job Insecurity, Job Dissatisfaction, Lack of Organisational Commitment, Poor Working Condition, Better Job Option, Job Stress and Unfair Treatments) were statistically significant in the prediction of employee turnover. Joubert et al. (2017) touched on the importance of competitive incentives and rewards in the attraction and retention of employees.

\section{AIM AND METHODOLOGICAL BASES}

In this section, we will discuss our research method with regard to construct measurement, data collection and reliability check.

The research aim was to determine how employer attractiveness influences the employees' intention to stay or leave to another organisation. The research utilised a quantitative design. We used an online questionnaire survey to collect data during the September and October 2019 among the Slovak SMEs' employees.

Random sampling technique was chosen to extract a representative sample for the population. In the first step, we choose the SMEs with non-zero income and number of employees in the year 2018 from the company database. In the second step, we randomly choose a specific company. In the third step, we asked one of the employees of the selected company to fill out a questionnaire. We used a stratified random sample to choose the company. The distinguishing criterion was the affiliation to SME categories, namely whether it was a micro $(\mathrm{N}=37,439)$, small $(\mathrm{N}=5,690)$ or medium-sized enterprise $(\mathrm{N}=1,266)$. There were 357 usable responses where 301 respondents were from micro (84.33 per cent), 46 from small (12.82 per cent), and 10 from medium-sized enterprise ( 2.85 per cent). In the sample, 52.94 per cent were women $(n=189), 37.62$ per cent were men $(n=168), 41.74$ per cent belonged to the Generation X ( $n=149), 29.97$ per to the Generation Y ( $n=106)$, and 28.29 per cent to the Generation $Z$ (101).

We measured EmpAt Scale (Berthon et al., 2005) using a seven-point Likert scale ranging from 1 (to a very little extent) to 7 (to a very great extent). Subscale components were calculated as the means of the individual responses because it is a more stable and unbiased estimate than are responses to any single item in the component. The instrument was chosen because it has already been employed by various international studies (Alnıaç1k \& Alnıaçık, 2012; Ha \& Luan, 2018; Germano et al., 2016; Reis et al., 2017; Sivertzen et al., 2013). Intention to stay or leave to another organisation was measured with the question "Are you consider staying or leave to another organisation within the next 6 months?" Some control variables were also included. Additional questions addressing information on gender, generation group, and managerial level affiliation were added.

As the current study was conducted in a Slovak speaking context, and the original measures of the studied constructs were in English, the survey instrument was translated from English into Slovak. Before administration of the survey, the questionnaires were distributed to researchers and several doctoral students. Some revisions in translation were made based on their feedback.

In order to reduce the potential influence of common method bias, data were collected at four time periods.

Table 1 presents the means, standard deviations and appropriate Cronbach's $\alpha$ coefficient for the summated total score (0.8636) and any subscale scores (Interest Value (IV) $=0.7631$; Social Value $(\mathrm{SV})=0.7846$; Application Value $\mathrm{AV}=0.8818$; Economic Value $\mathrm{EV}=0.7588$; Development Value $\mathrm{DV}=0$.). The Cronbach's alphas above 0.7 indicate acceptable internal consistency of the constructs. 
Table 1 Survey's results

\begin{tabular}{|c|c|c|c|}
\hline COMPONENTS & $\begin{array}{c}\text { ITEM } \\
\text { MEAN } \\
\text { (SEVEN- } \\
\text { POINT } \\
\text { LIKERT } \\
\text { SCALE) }\end{array}$ & $\begin{array}{l}\text { STD } \\
\text { DEV }\end{array}$ & $\begin{array}{l}\text { CRONBACH } \\
\text { ALPHA }\end{array}$ \\
\hline Interest Value (IV) & 4.67 & 0.77 & 0.8042 \\
\hline IV01_Working in a vibrant/challenging environment & 4.71 & 0.99 & \\
\hline $\begin{array}{l}\text { IV02_Innovative employer - novel work } \\
\text { practices/forward-thinking }\end{array}$ & 4.64 & 1.06 & \\
\hline $\begin{array}{l}\text { IV03_The organisation both values and makes use of } \\
\text { your creativity }\end{array}$ & 4.62 & 1.02 & \\
\hline $\begin{array}{c}\text { IV04_The organisation produces high-quality } \\
\text { products and services }\end{array}$ & 4.64 & 1.03 & \\
\hline $\begin{array}{l}\text { IV05_The organisation produces innovative products } \\
\text { and services }\end{array}$ & 4.72 & 1.06 & \\
\hline Social Value (SV) & 4.41 & 0.89 & 0.8463 \\
\hline $\begin{array}{l}\text { SV01_Having a good relationship with your } \\
\text { colleagues }\end{array}$ & 4.39 & 0.86 & \\
\hline SV02_Having a good relationship with your superiors & 4.44 & 1.09 & \\
\hline SV03_Supportive and encouraging colleagues & 4.43 & 1.16 & \\
\hline SV04_Happy work environment & 4.36 & 1.15 & \\
\hline Application Value (AV) & 4.39 & 0.76 & 0.7859 \\
\hline $\begin{array}{l}\text { AV01_Humanitarian organisation - gives back to } \\
\text { society }\end{array}$ & 4.34 & 0.88 & \\
\hline $\begin{array}{c}\text { AV02_Opportunity to apply what was learned in } \\
\text { college/university }\end{array}$ & 4.57 & 1.10 & \\
\hline $\begin{array}{l}\text { AV03_Opportunity to teach others what you have } \\
\text { learned }\end{array}$ & 4.33 & 0.97 & \\
\hline AV04_Acceptance and belonging & 4.33 & 1.07 & \\
\hline AV05_The organisation is customer-orientated & 4.38 & 1.16 & \\
\hline Economic Value (EV) & 4.41 & 1.16 & 0.8727 \\
\hline $\begin{array}{c}\text { EV01_Good promotion opportunities within the } \\
\text { organisation }\end{array}$ & 4.41 & 1.17 & \\
\hline EV02_An above average basic salary & 4.34 & 1.30 & \\
\hline EV03_An attractive overall compensation package & 4.48 & 1.42 & \\
\hline Development Value (DV) & 4.45 & 0.81 & 0.7456 \\
\hline $\begin{array}{l}\text { DV01_Feeling more self-confident as a result of } \\
\text { working for a particular organisation }\end{array}$ & 4.41 & 0.80 & \\
\hline $\begin{array}{c}\text { DV02_Feeling good about yourself as a result of } \\
\text { working for a particular organisation }\end{array}$ & 4.45 & 1.25 & \\
\hline DV03_Gaining career-enhancing experience & 4.50 & 1.24 & \\
\hline Entire Set & & & 0.8863 \\
\hline $\begin{array}{l}\text { Are you consider staying or leave to another } \\
\text { organisation within the next } 6 \text { months? (ISL) }\end{array}$ & $\mathbf{n}$ & $\begin{array}{l}\text { \% of } \\
\text { Total }\end{array}$ & \\
\hline Leave & 125 & $35.01 \%$ & \\
\hline Stay & 232 & $64.99 \%$ & \\
\hline
\end{tabular}




\section{RESULTS}

(Source: Authors calculations)

The goal of the building model is to estimate the likelihood that dummy binary variable is either "stay" (1) or "leave" (0) and thus which factors more lead to intention to stay in the organisation within the next six months.

To build the model, we started with all possible predictors as effects. The first model's lack of fit report showed that the model fits the data well (0.8693). As Table 2 presents, there are four significant parameters $(\mathrm{IV}=0.0006, \mathrm{SV}=0.0286, \mathrm{AV}=0.0009, \mathrm{EV}=0.0003)$ and one non-significant parameter $(\mathrm{DV}=0.1806)$. The misclassification rate of the first model also proved that only 15.41 per cent responses are not the observed category.

In the second model, we decided to exclude the non-significant parameter (DV). The lack of fit report showed that the model also fit the data well (0.8047) and the misclassification rate of the second model is better than the first model since only 14.29 per cent responses are not the observed category.

Table 2 Building models - lack of fit report, the misclassification rate and parameter estimates

\begin{tabular}{|c|c|c|c|c|}
\hline FIRST MODEL & "ESTIMATE & "STD ERROR & CHISQUARE & PROB $>$ CHISQ \\
\hline Intercept & -12.6845447 & 1.670350302 & 57.67 & $<.0001$ \\
\hline Interest Value & 0.768849238 & 0.222881536 & 11.9 & 0.0006 \\
\hline Social Value & 0.389105693 & 0.177809903 & 4.79 & 0.0286 \\
\hline Application Value & 0.837345059 & 0.253176722 & 10.94 & 0.0009 \\
\hline Economic Value & 0.71912028 & 0.200495037 & 12.86 & 0.0003 \\
\hline \multirow[t]{2}{*}{ Development Value } & 0.363235847 & 0.271269814 & 1.79 & 0.1806 \\
\hline & DF & $\begin{array}{c}- \\
\text { LogLikelihood }\end{array}$ & ChiSquare & Prob $>$ ChiSq \\
\hline Lack of Fit & 350 & 160.24378 & 320.4876 & 0.8693 \\
\hline \multicolumn{4}{|c|}{ Misclassification Rate $\sum(\varrho[j] \neq \varrho M a x) / n$} & 0.1541 \\
\hline Second model & Estimate & Std Error & ChiSquare & Prob $>$ ChiSq \\
\hline Intercept & -12.24457226 & 1.630965801 & 56.36 & $<.0001$ \\
\hline Interest Value & 0.800442254 & 0.221557834 & 13.05 & 0.0003 \\
\hline Social Value & 0.392446061 & 0.17729809 & 4.9 & 0.0269 \\
\hline Application Value & 0.9299242 & 0.243358226 & 14.6 & 0.0001 \\
\hline \multirow[t]{2}{*}{ Economic Value } & 0.858328006 & 0.172163383 & 24.86 & $<.0001$ \\
\hline & DF & $\begin{array}{c}- \\
\text { LogLikelihood }\end{array}$ & ChiSquare & Prob $>$ ChiSq \\
\hline Lack of Fit & 345 & 161.14837 & 322.2967 & 0.8047 \\
\hline \multicolumn{4}{|c|}{ Misclassification Rate $\sum(\varrho[j] \neq \varrho M a x) / n$} & 0.1429 \\
\hline
\end{tabular}

(Source: Authors calculations)

Table 3 Predictors unit odds ratios

\begin{tabular}{||c|c|c|c|c||}
\hline \hline TERM & $\begin{array}{c}\text { ODDS } \\
\text { RATIO }\end{array}$ & LOWER 95\% & UPPER 95\% & RECIPROCAL \\
\hline Interest Value (IV) & 2.226525401 & 1.442239162 & 3.43730464 & 0.44913029 \\
\hline Social Value (SV) & 1.480598002 & 1.045973668 & 2.095818 & 0.675402776 \\
\hline Application Value (AV) & 2.53431707 & 1.572946861 & 4.08326764 & 0.394583619 \\
\hline Economic Value (EV) & 2.359212805 & 1.683532016 & 3.30607616 & 0.423870199 \\
\hline
\end{tabular}


(Source: Authors calculations)

We also calculate log-odds, which are presented in Table 3 to predict which employer attractiveness factor leads to an intention to stay in the organisation within the next 6 months. Because of the higher the $\log$-odds are, the more likely the reference event is, we can conclude that to the employee's decision to stay working for the organisation contribute AV (Odds Ratio=2.53), followed by EV (Odds Ratio=2.36), IV (Odds Ratio=2.23), and SV (Odds Ratio=1.48). The odds ratios can be interpreted as follows for each additional point in AV the probability of the event (staying in the organisation within the next 6 months) increases about 92.82 per cent $(=\ln 2.53)$, provided that the other predictors are unchanged.)

\section{CONCLUSION}

Employee turnover is a problem for organisations and is one of the challenges facing human resource managers (Asimah, 2018). The good recruitment program can provide a positive influence on increasing employee commitment, productivity and the quality of work, including performance. The relationship of employee retention on performance is exceedingly complex (Sutanto \& Kurniawan, 2016).

The paper objective was to answer the questions of whether employer attractiveness influences the employees' intention to stay or leave to another organisation and also whether it is possible to identify factors with a significant effect on the intention to stay or leave. Results showed that to the employee's decision to stay working for the organisation contribute Application Value (AV Odds Ratio=2.53), followed by Economic Value (EV Odds Ratio=2.36), Interest Value (IV Odds Ratio=2.23), and Social Value (SV Odds Ratio=1.48). These results are consistent with the researches presented in the literature review. Surprisingly, though the Slovak economy focuses on cheap labour (Habánik et al., 2019), EV was even the second most important factor decisive for intention to stay. We also did not find statistically significant associations between Development Value (DV) and the employees' intention to stay or leave (ISL). The result may indicate that the bulk of businesses do not take seriously internal marketing, and thus employees are not identified with the companies they are work for.

This study makes several contributions to extant human resource management literature. First, it extends the research on employer attractiveness and employee retention. Second, it expands the knowledge about the predictors of employees' intention to stay in organisations.

It is recommended that the organisation regularly measures employees' intent to stay or leave to ensure that employees are still aware of the benefits of the company's current policies. The organisation should also identify promptly any problems that cause employee dissatisfaction and try to resolve them before employees are aware of them.

The current paper provides several implications for theory and practice, but some limitations should be discussed. The self-reported questionnaire could cause response bias from a misunderstanding of what a proper measurement is to social-desirability bias, where the respondent wants to 'look good' in the survey, even if the survey is anonymous (Rosenman et al., 2011). Additionally, it uses a sample without the sole traders (they do not have an obligation to disclose financial statements in the Slovak Republic, which, in some way, influences the generalizability of the results.

It would be interesting to investigate how the intention to stay or leave differs according to gender, managerial level and Hofstede's cultural dimensions theory. Further research should perform a more granular data analysis and determine which value propositions individual respondents praise and complain about. Finally, we encourage future studies to address why employees are not identified with the companies they are work for. 


\section{REFERENCES}

Aiman-Smith, L., Bauer, T. N., \& Cable, D. M. (2001). Journal of Business and Psychology, 16(2), 219-237. doi:10.1023/a:1011157116322

Alnıaçık, E., \& Alnıaçı, Ü. (2012). Identifying Dimensions of Attractiveness in Employer Branding: Effects of Age, Gender, and Current Employment Status. Procedia - Social and Behavioral Sciences, 58, 1336-1343. doi:10.1016/j.sbspro.2012.09.1117

Altmann, S., \& Suess, S. (2015). The influence of temporary time offs from work on employer attractiveness - An experimental study. Management Revue, 26(4), 282-305. doi:10.5771/0935-99152015-4-282

Alzyoud, A. A. Y., Ahmed, U., AlZgool, M. R. H., \& Pahi, M. H. (2019). Leaders' emotional intelligence and employee retention: Mediation of job satisfaction in the hospitality industry. International Journal of Financial Research, 10(3), 1-10. doi:10.5430/ijfr.v10n3p1

Ambler, T., \& Barrow, S. (1996). The employer brand. The Journal of Brand Management, 4(3), 185-206. doi:https://doi.org/10.1057/bm.1996.42

Arachchige, B. J. H., \& Robertson, A. (2011). Business Student Perceptions of a Preferred Employer: A Study Identifying Determinants of Employer Branding. The IUP Journal of Brand Management, $\operatorname{VIII}(3)$.

Arasanmi, C. N., \& Krishna, A. (2019). Employer branding: perceived organisational support and employee retention - the mediating role of organisational commitment. Industrial and Commercial Training, 51(3), 174-183. doi:10.1108/ICT-10-2018-0086

Asimah, V. K. (2018). Factors that influence labour turnover intentions in the hospitality industry in Ghana. African Journal of Hospitality, Tourism and Leisure, 7(1). Retrieved from https://www.scopus.com/inward/record.uri?eid=2-s2.085042480161\&partnerID $=40 \& \mathrm{md} 5=\mathrm{d} 1 \mathrm{f} 7 \mathrm{c} 88 \mathrm{f} 083936 \mathrm{a} 4 \mathrm{c} 0 \mathrm{c} 4 \mathrm{daf3f8c} 49347$

Bakanauskiene, I., Bendaravičiene, R., \& Barkauske, L. (2017). Organizational attractiveness: An empirical study on employees attitudes in lithuanian business sector. Problems and Perspectives in Management, 15(2), 4-18. doi:10.21511/ppm.15(2).2017.01

Berthon, P., Ewing, M., \& Hah, L. L. (2005). Captivating company: dimensions of attractiveness in employer branding. International Journal of Advertising, 24(2), 151-172. doi:10.1080/02650487.2005.11072912

Bigsby, K. G., Ohlmann, J. W., \& Zhao, K. (2019). The turf is always greener: Predicting decommitments in college football recruiting using Twitter data. Decision Support Systems, 116, 112. doi:10.1016/j.dss.2018.10.003

Breaugh, J. A., \& Starke, M. (2000). Research on employee recruitment: so many studies, so many remaining questions. Journal of Management, 26(3), 405-434. doi:https://doi.org/10.1016/S01492063(00)00045-3

Cascio, W. (2019). Managing Human Resources 11th Edition: McGraw-Hill Higher Education.

Cepel, M., Stasiukynas, A., Kotaskova, A., \& Dvorsky, J. (2018). Business Environment Quality Index in the Sme Segment. Journal of Competitiveness, 10(2), 21-40. doi:10.7441/joc.2018.02.02

Dabirian, A., Kietzmann, J., \& Diba, H. (2017). A great place to work!? Understanding crowdsourced employer branding. Business Horizons, 60(2), 197-205. doi:10.1016/j.bushor.2016.11.005

Dabirian, A., Paschen, J., \& Kietzmann, J. (2019). Employer Branding: Understanding Employer Attractiveness of IT Companies. IT Professional, 21(1), 82-89. doi:10.1109/MITP.2018.2876980

Dahnil, M. I., Marzuki, K. M., Langgat, J., \& Fabeil, N. F. (2014). Factors Influencing SMEs Adoption of Social Media Marketing. Procedia - Social and Behavioral Sciences, 148, 119-126. doi:10.1016/j.sbspro.2014.07.025

Govaerts, N., Kyndt, E., Dochy, F., \& Baert, H. (2011). Influence of learning and working climate on the retention of talented employees. Journal of Workplace Learning, 23(1), 35-55. doi:10.1108/13665621111097245

Ha, N. M., \& Luan, N. V. (2018). The effect of employers' attraction and social media on job application attention of senior students at pharmaceutical universities in Vietnam. International Journal of Business and Society, 19(2), 473-491. Retrieved from 
https://www.scopus.com/inward/record.uri?eid=2-s2.0$\underline{85052849446 \& p a r t n e r I D=40 \& m d 5=9 e 7 a 3 c 3 a b 67583 d 533402 e d 806 b 2 c d 53}$

Habánik, J., Grenčíková, A., \& Krajčo, K. (2019). New technology impact on the Sustainable Development. Engineering Economics, 30(1). doi:10.5755/j01.ee.30.1.20776

Helm, S. (2013). A Matter of Reputation and Pride: Associations between Perceived External Reputation, Pride in Membership, Job Satisfaction and Turnover Intentions. British Journal of Management, 24(4), 542-556. doi:10.1111/j.1467-8551.2012.00827.x

Highhouse, S., Lievens, F., \& Sinar, E. F. (2003). Measuring Attraction to Organizations. Educational and Psychological Measurement, 63(6), 986-1001. doi:10.1177/0013164403258403

Hiltrop, J.-M. (1999). The quest for the best: human resource practices to attract and retain talent. European Management Journal, 17(4), 422-430. doi:https://doi.org/10.1016/S0263-2373(99)00022-5

Jiang, T., Lu, L., \& Iles, P. (2011). Employer-brand equity, organizational attractiveness and talent management in the Zhejiang private sector, China. Journal of Technology Management in China, 6(1), 97-110. doi:10.1108/17468771111105686

Joubert, P., Madau, D., \& Grobler, B. (2017). Employee retention and talent management at a sugar mill in South Africa. Problems and Perspectives in Management, 15(3), 306-315. doi:10.21511/ppm.15(3-1).2017.14

Kausel, E. E., \& Slaughter, J. E. (2011). Narrow personality traits and organizational attraction: Evidence for the complementary hypothesis. Organizational Behavior and Human Decision Processes, 114(1), 3-14. doi:10.1016/j.obhdp.2010.08.002

Kljucnikov, A., Belas, J., Kozubikova, L., \& Pasekova, P. (2016). The Entreprenurial Perception of SME Business Environment Quality in the Czech Republic. Journal of Competitiveness, 8(1), 66-78. doi:10.7441/joc.2016.01.05

Koisova, E., Habanik, J., Virglerova, Z., \& Rozsa, Z. (2017). SMEs Financing as an Important Factor of Business Environment in Slovak Republic Regions. Montenegrin Journal of Economics, 13(2), 129140. doi:10.14254/1800-5845/2017.13-2.8

Kossivi, B., Xu, M., \& Kalgora, B. (2016). Study on Determining Factors of Employee Retention. Open Journal of Social Sciences, 04(05), 261-268. doi:10.4236/jss.2016.45029

Lievens, F., Decaesteker, C., Coetsier, P., \& Geirnaert, J. (2001). Organizational Attractiveness for Prospective Applicants: A Person-Organisation Fit Perspective. Applied Psychology, 50(1), 30-51. doi:10.1111/1464-0597.00047

Matongolo, A., Kasekende, F., \& Mafabi, S. (2018). Employer branding and talent retention: perceptions of employees in higher education institutions in Uganda. Industrial and Commercial Training, 50(5), 217-233. doi:10.1108/ICT-03-2018-0031

Mattox Ii, J. R., \& Jinkerson, D. L. (2005). Using survival analysis to demonstrate the effects of training on employee retention. Evaluation and Program Planning, 28(4), 423-430. doi:10.1016/j.evalprogplan.2005.07.006

Mihalache, F., Tantau, M., Diaconu, B., \& Acalovschi, M. (2010). Survival and quality of life of cholangiocarcinoma patients: a prospective study over a 4 year period. J Gastrointestin Liver Dis, 19(3), 285-290. Retrieved from https://www.ncbi.nlm.nih.gov/pubmed/20922193

Mura, L. (2019). ENTREPRENEURSHIP INTERNATIONALIZATION - CASE OF SLOVAK FAMILY BUSINESSES. Ad Alta-Journal of Interdisciplinary Research, 9(1), 222-226. Retrieved from $<$ Go to ISI >://WOS:000474385400039

Mutsuddi, I., \& Sinha, C. (2017). Role of collectivistic, individualistic approaches and social factors for employee retention: A study on selected IT organizations in the NCR of Delhi. International Journal of Applied Business and Economic Research, 15(1), 327-347. Retrieved from https://www.scopus.com/inward/record.uri?eid=2-s2.085013787353\&partnerID $=40 \& \mathrm{md} 5=61 \mathrm{f5e} 32 \mathrm{f} 0224 \mathrm{~d} 5 \mathrm{bd} 3 \mathrm{~d} 83726 \mathrm{~d} 1 \mathrm{e} 0 \mathrm{f} 30 \mathrm{~b} 8$

Pavlovic, G. (2018). Employer attractiveness and the employee turnover and retention Paper presented at the Second international scientific conference itema 2018, Graz University of Technology, Graz, Austria. 
Peter, M., Kavitha, S. F., \& Ramamoorthy, R. (2019). Employee retention management. International Journal of Recent Technology and Engineering, $8(2$ Special Issue 8), 18-20. doi:10.35940/ijrte.B1305.0882S819

Pittino, D., Visintin, F., Lenger, T., \& Sternad, D. (2016). Are high performance work practices really necessary in family SMEs? An analysis of the impact on employee retention. Journal of Family Business Strategy, 7(2), 75-89. doi:10.1016/j.jfbs.2016.04.002

Rakhra, H. K. (2018). Study on factors influencing employee retention in companies. International Journal of Public Sector Performance Management, 4(1), 57-79. doi:10.1504/IJPSPM.2018.10009505

Reis, G. G., \& Braga, B. M. (2016). Employer attractiveness from a generation perspective: Implications for employer branding. Revista de Administração, 51(1), 103-116. doi:10.5700/rausp1226

Reis, G. G., Braga, B. M., \& Trullen, J. (2017). Workplace authenticity as an attribute of employer attractiveness. Personnel Review, 46(8), 1962-1976. doi:10.1108/pr-07-2016-0156

Rosenman, R., Tennekoon, V., \& Hill, L. G. (2011). Measuring bias in self-reported data. Int J Behav Healthc Res, 2(4), 320-332. doi:10.1504/IJBHR.2011.043414

Rynes, S., Bretz, B., \& Gerhart, B. (1991). The importance of recruitment in job choice: A different way of looking Personnel Psychology, Vol. 44, pp. 487-521., 44, 487-521.

Sivertzen, A. M., Nilsen, E. R., \& Olafsen, A. H. (2013). Employer branding: employer attractiveness and the use of social media. Journal of Product and Brand Management, 22(7), 473-+. doi:10.1108/jpbm-09-2013-0393

Slåtten, T., Lien, G., \& Svenkerud, P. J. (2019). The role of organizational attractiveness in an internal market-oriented culture (IMOC): A study of hospital frontline employees. BMC Health Services Research, 19(1). doi:10.1186/s12913-019-4144-8

Stachová, K., Papula, J., Stacho, Z., \& Kohnová, L. (2019). External Partnerships in Employee Education and Development as the Key to Facing Industry 4.0 Challenges. Sustainability, 11(2). doi: $10.3390 /$ su11020345

Sutanto, E. M., \& Kurniawan, M. (2016). The impact of recruitment, employee retention and labor relations to employee performance on batik industry in Solo city, Indonesia. International Journal of Business and Society, 17(2), 375-390. Retrieved from https://www.scopus.com/inward/record.uri?eid=2-s2.084983411163\&partnerID =40\&md5=121 ce9714834be0ffa290dee530ed54d

Turban, D. B. (2001). Organizational Attractiveness as an Employer on College Campuses: An Examination of the Applicant Population. Journal of Vocational Behavior, 58(2), 293-312. doi:https://doi.org/10.1006/jvbe.2000.1765

Uen, J. F., Peng, S.-P., Chen, S.-Y., \& Chien, S. H. (2011). The Impact of Word of Mouth on Organizational Attractiveness. Asia Pacific Management Review, 16(3), 239-253.

Yu, Q., Yen, D. A., Barnes, B. R., \& Huang, Y. A. (2019). Enhancing firm performance through internal market orientation and employee organizational commitment. International Journal of Human Resource Management, 30(6), 964-987. doi:10.1080/09585192.2017.1380059 